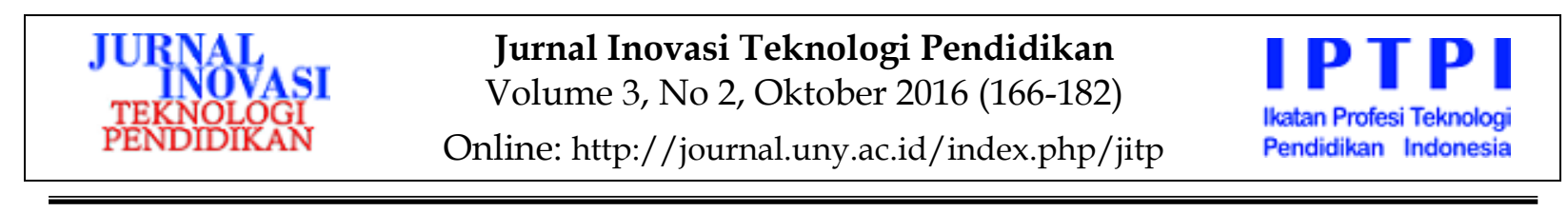

\title{
PENGEMBANGAN MEDIA PEMBELAJARAN BERBASIS WEB MATA PELAJARAN ILMU PENGETAHUAN ALAM UNTUK SISWA KELAS VII
}

\author{
Erwin Januarisman, Anik Ghufron \\ SMK N 1 Kopang Nusa Tenggara Barat, Universitas Negeri Yogyakarta \\ erwin.januarisman27@gmail.com, anikgh@telkom.net
}

\begin{abstract}
Abstrak
Penelitian ini bertujuan untuk: (1) menghasilkan produk berupa media pembelajaran IPA berbasis web. (2) mengetahui tingkat kelayakan dan keefektifan media pembelajaran IPA berbasis web. Jenis penelitian ini adalah penelitian dan pengembangan (R\&D) yang menggunakan metode penelitian Borg \& Gall dan metode pengembangan Alessi \& Trollip. Prosedur pengembangan meliputi tahap perencanaan, desain, dan pengembangan. Penelitian menunjukan hasil sebagai berikut. (1) Produk berupa media pembelajaran berbasis web pada mata pelajaran IPA menggunakan software CMS (Content Management System) Wordpress. (2) Produk media pembelajaran berbasis web pada mata pelajaran IPA telah dinyatakan layak sebagai media pembelajaran berdasarkan hasil validasi dari ahli materi dengan nilai rata-rata 3,98 dengan kategori "Baik", ahli media dengan nilai rata-rata 4,07 dengan kategori "Baik", uji coba lapangan awal diperoleh rata-rata penilaian sebesar 4,13 dengan kategori "Baik" dan uji coba lapangan utama diperoleh nilai gain untuk SMP Muhammadiyah 2 sebesar 22,2, SMP N 2 sebesar 24, SMP N 3 sebesar 21,6 dan SMP N 5 sebesar 19,6. (3) Keefektifan media pembelajaran IPA berbasis web dibuktikan dengan meningkatnya hasil belajar siswa berdasarkan data hasil evaluasi pretest dan posttest.
\end{abstract}

Kata kunci: efektivitas, media pembelajaran berbasis web, IPA.

\section{DEVELOPING WEB-BASED LEARNING MEDIA ON NATURAL SCIENCES LESSON FOR THE SECOND YEAR STUDENTS OF SMP}

\author{
Erwin Januarisman, Anik Ghufron \\ SMK N 1 Kopang NTB, Universitas Negeri Yogyakarta \\ erwin.januarisman27@gmail.com, anikgh@telkom.net
}

\begin{abstract}
The purposes of this research were to: (1) generate product in the form of web-based science learning media. (2) reveal the feasibility and effectiveness of the product developed. The type of this research was a research and development (RED) using method by Borg and Gall and method development by Alessi \& Trollip. The development procedure included the planning, design, and development. The results of this research is as follows. (1) A product of media web-based learning in science subjects was developed using software CMS (Content Management System) Wordpress. (2) The product was considered eligible as a medium of learning based on the results of the validation of materials expert with an average score of 3.98 with the category of "good", media experts average score is 4.07 with the category of "Good", the initial field trial score is 4.13 with the category "good", and the main field trials score obtained for SMP Muhammadiyah 2 is 22.2, SMP N 2 is 24, SMP N 3 is 21.6 and SMP N 5 is 19.6. (3) The effectiveness of the web-based science learning media is shown by the increase of student learning outcomes based on evaluation data of pretest and posttest.
\end{abstract}

Keywords: effectiveness, media web-based learning, Natural Sciences Lesson. 



\section{Pendahuluan}

Teknologi pendidikan yang dikenal juga dengan teknologi pembelajaran (instructional technology) merupakan suatu bidang studi terapan yang hadir sebagai suatu usaha terpadu untuk membantu memecahkan masalah belajar yang belum terpecahkan dengan pendekatan yang telah ada sebelumnya. Dari tahun ke tahun terminologi teknologi pendidikan telah berkembang. Association Education Communication and Technology (2004, p.3) mendefinisikan teknologi pendidikan sebagai studi dan praktik dalam memfasilitasi belajar dan meningkatkan kinerja dengan menciptakan, menggunakan dan mengelola proses dan sumber teknologi yang tepat. Salah satu landasan konsep teknologi pendidikan muncul karena perlu adanya usaha untuk mengidentifikasi hal-hal yang belum jelas atau belum terpecahkan dan mencari caracara baru yang inovatif sesuai dengan perkembangan budaya dan hasrat manusia serta mengelola potensi-potensi sumber belajar agar dapat digunakan secara optimal untuk keperluan belajar (Miarso, 2005, p.121).

Teknologi pembelajaran muncul seiring dengan perkembangan zaman. Jika zaman dulu pembelajaran hanya mengandalkan kehadiran guru dan siswa, maka di zaman kemajuan teknologi internet yang serba mobile ini, teknologi pembelajaran sangat diperlukan. Landasan ontologi timbulnya konsep teknologi pembelajaran antara lain: (1) adanya sejumlah besar orang yang belum terpenuhi kesempatan belajarnya, (2) adanya sumber yang belum dapat dimanfaatkan untuk keperluan belajar, (3) perlu adanya usaha untuk menggarap sumber-sumber tersebut agar dapat terpenuhi hasrat belajar setiap orang, (4) perlunya pengelolaan sumber-sumber belajar agar bisa digunakan secara optimal untuk keperluan belajar (Miarso, 2005, p.166).

Penetrasi pengguna internet di Indonesia menurut riset yang dilakukan oleh Asosiasi Penyelenggara Jasa Internet Indonesia (APJII) bekerjasama dengan Pu- sat Kajian Komunikasi (PusKaKom) Universitas Indonesia (UI) dalam rangka untuk menemukan jawaban pertumbuhan pengguna tahun 2014 mengungkapkan bahwa jumlah pengguna internet di Indonesia mencapai 88 juta orang hingga akhir tahun 2014. Berdasarkan populasi, jumlah pengguna internet terbanyak adalah di provinsi Jawa Barat sebanyak 16.4 juta, diikuti oleh Jawa Timur 12.1 juta pengguna dan Jawa Tengah 10.7 juta pengguna. Sedangkan jumlah pengguna internet di D.I Yogyakarta sebanyak 2 juta pengguna.

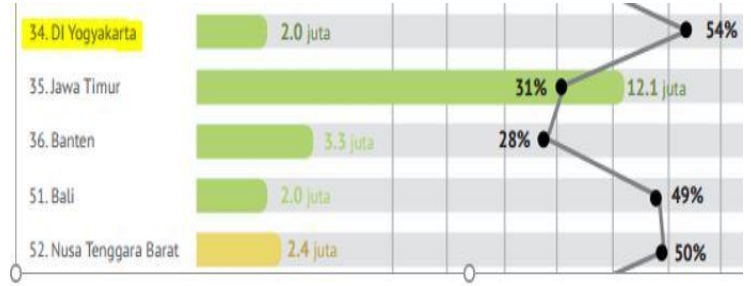

Gambar 1. Jumlah Pengguna Internet di D.I Yogyakarta Tahun 2014

Sedangkan grafik jumlah dan penetrasi pengguna internet di Indonesia tahun 2005-2014 dapat dilihat pada Gambar 2.

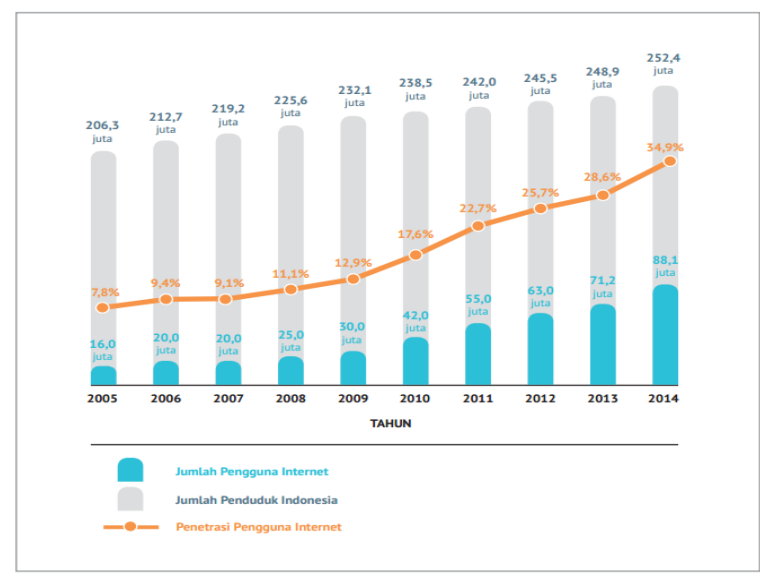

Gambar 2. Grafik Jumlah dan Penetrasi Pengguna Internet di Indonesia Tahun 2005 - 2014

Berdasarkan data tersebut terlihat bahwa D.I Yogyakarta mempunyai pengguna internet sebanyak 2 juta pengguna dan jumlah pengguna internet di Indonesia dari tahun 2005 sampai 2014 mengalami peningkatan grafik pengguna internet. Perkembangan internet juga telah merubah 
kondisi pembelajaran yang selalu terikat dengan ruang dan waktu menjadi pembelajaran yang bisa dilaksanakan kapan saja dan dimana saja.

Pembelajaran menggunakan internet perlu dilaksanakan pada seluruh mata pelajaran untuk jenjang pendidikan menengah, tanpa terkecuali mata pelajaran Ilmu Pengetahuan Alam (IPA). Pembelajaran IPA merupakan pembelajaran yang mengaitkan semua bidang kajian IPA yaitu Fisika, Kimia, dan Biologi. Murpy (Surjono, 2012, p.15) mengemukakan bahwa pembelajaran IPA di Sekolah Dasar dan Menengah terutama bertujuan untuk mengembangkan kemampuan proses ilmiah, mendorong pemahaman konsep dan mengembangkan sikap positif terhadap ilmu pengetahuan. Sikap positif terhadap ilmu pengetahuan harus didukung dengan beragamnya sumber belajar dan media pembelajaran.

Faktanya sumber belajar dan media pembelajaran berbasis web yang dapat mendukung kegiatan pembelajaran IPA masih sangat terbatas. Media pembelajaran yang digunakan berdasarkan angket guru hasil analisis kebutuhan, guru baru sebatas menggunakan buku cetak, LKS, OHP, papan tulis dan LCD. Guru belum menerapkan media pembelajaran IPA berbasis web dalam kegiatan belajar mengajar, padahal mata pelajaran IPA khususnya pada jenjang SMP/MTS memuat cakupan materi yang cukup luas. Masalah yang berkaitan dengan keterbatasan sumber dan media pembelajaran tentu sangat tidak sejalan dengan perkembangan teknologi yang semakin modern dan canggih. Kecanggihan teknologi semestinya memudahkan siswa untuk mengakses sumber daya yang berkualitas. Mengembangkan sumber belajar yang berkualitas serta berbasis digital pada pembelajaran telah menjadi bagian terpenting dalam membangun sistem pendidikan berbasis informasi (Zhu, 2010, p.1). Urgensi terhadap masalah ini tidak hanya ditemukan di sebagian kecil sekolah tapi hampir sebagian besar sekolah.

Berdasarkan hasil prasurvey yang dilaksanakan di SMP se-Kecamatan Depok
Sleman pada bulan Maret 2015 teridentifikasi beberapa masalah dan kendala dalam proses pembelajaran khususnya pada pembelajaran IPA diantaranya minat belajar peserta didik rendah terlihat dari kurangnya perhatian dan antusiasme dalam mengikuti pelajaran sehingga guru mengalami kesulitan dalam mengampu mata pelajaran IPA. Metode pembelajaran yang sering digunakan dalam proses pembelajaran di sekolah adalah metode ceramah, diskusi, demonstrasi, eksperimen dan problem based learning (PBL). Sedangkan media pembelajaran yang sering digunakan guru dalam proses pembelajaran adalah buku cetak, LKS, OHP, papan tulis dan LCD. Berdasarkan angket guru hasil analisis kebutuhan, guru mengalami berbagai kendala dalam mengampu mata pelajaran IPA. Hal ini ditunjukkan oleh sikap peserta didik yang kurang perhatian dan kurang antusias dalam mengikuti pelajaran, peserta didik mengalami kesulitan dalam menangkap pelajaran, guru sulit mengajarkan materi secara tuntas dalam kurun waktu yang relatif singkat, peserta didik kurang aktif dalam pembelajaran dan guru kesulitan dalam menyampaikan materi yang membutuhkan penyajian materi dalam bentuk multimedia, seperti media teks, gambar, animasi, audio, video, animasi dan e-book digital secara bersamaan. Memperhatikan hal tersebut, kemungkinan metode dan media yang digunakan dalam pembelajaran masih kurang tepat sehingga berpengaruh pada kegiatan belajar mengajar di sekolah.

Pemanfaatan fasilitas laboratorium komputer dan jaringan internet belum dimanfaatkan secara optimal oleh pihak sekolah. Daya dukung fasilitas sekolah sudah cukup memadai seperti listrik, komputer, jaringan internet, serta bekal keahlian siswa dalam mengakses intenet belum sejalan dengan pemanfaatannya dalam proses pembelajaran. Website khusus yang dimiliki sekolah hanya dimanfaatkan untuk kepentingan profil sekolah dan belum dimanfaatkan untuk mendukung kegiatan pembelajaran. Laboratorium komputer digunakan hanya untuk kegiatan pembelajar- 
an TIK saja sehingga mata pelajaran lain belum terakomodir. Siswa sebetulnya sudah dibekali dengan keahlian dalam penggunaan komputer dan internet tetapi pemanfaatannya masih terbatas pada pembelajaran TIK. Hal tersebut tentu beralasan karena memang belum ada media pembelajaran berbasis web yang dapat mengakomodasi kegiatan pembelajaran IPA.

Berdasarkan analisis terhadap kendala dan permasalah yang muncul pada pembelajaran maka diperlukan solusi yang tepat dan bermanfaat agar pembelajaran IPA dapat mencapai tujuan dan kompetensi yang diinginkan. Melalui pembelajaran yang memanfaatkan teknologi dan media pembelajaran seharusnya memberikan akses dan kesempatan seluas-luasnya bagi siswa membangun pengetahuannya sendiri dengan mengakses sumber belajar yang ada melalui media pembelajaran sehingga tujuan pembelajaran akan mudah dicapai. Upaya untuk memberikan akses terhadap sumber belajar yang memadai dapat dilakukan melalui media pembelajaran berbasis web.

Konsep yang terkenal dengan sebutan e-learning atau media pembelajaran berbasis web ini membawa pengaruh terjadinya proses transformasi pembelajaran menuju bentuk digital, baik secara isi (content) maupun sistemnya. Media pembelajaran berbasis web merupakan sebuah inovasi yang mempunyai kontribusi sangat besar terhadap perubahan proses pembelajaran, proses belajar tidak lagi hanya mendengarkan uraian materi dari pendidik tetapi siswa juga melakukan aktivitas lain seperti mengamati, melakukan, mendemonstrasikan dan lainnya. Surjono (2013, p.19) mengemukakan bahwa media pembelajaran berbasis web atau e-learning yang kini menjadi sangat populer karena flexibilitas dan efektivitasnya merupakan cara penyampaian materi pembelajaran melalui internet yang dapat diakses kapan saja dan dari mana saja. Melalui media pembelajaran berbasis web dan sumber daya memadai materi pembelajaran dapat diakses kapan saja dan dimana saja. Materi pem- belajaran dapat diperkaya dengan berbagai sumber belajar termasuk multimedia dan dengan cepat dapat diperbaharui oleh pengajar, maka pembelajaran IPA dapat juga memanfaatkan keunggulan media pembelajaran berbasis web ini.

SMP se-Kecamatan Depok Sleman sudah mempunyai website sekolah. Namun penggunaannya masih sebatas hanya untuk menampilkan profil sekolah dan belum menerapkan media pembelajaran berbasis web yang khusus menyajikan materi-materi pembelajaran, padahal menurut Kruse (Rusman, 2012, p.294) pembelajaran berbasis web seringkali memiliki manfaat yang banyak bagi para peserta didik. Bila dirancang dengan baik dan tepat, maka pembelajaran berbasis web bisa menjadi pembelajaran yang menyenangkan dan memiliki unsur interaktifitas yang tinggi sehingga dapat membuat peserta didik mengingat lebih banyak materi pelajaran yang diajarkan. Berdasarkan kuesioner, ada beberapa kendala utama guru dalam penerapan media pembelajaran berbasis web di sekolah, seperti: guru belum menguasai media pembelajaran berbasis web, beban tugas guru yang sudah banyak, keterbatasan dana dan keterbatasan waktu pengelolaan. Disamping itu, hasil kuesioner kepada peserta didik juga menunjukkan bahwa pembelajaran IPA merupakan pembelajaran yang sulit dipahami. Menurut peserta didik, sulitnya memahami materimateri IPA disebabkan beberapa faktor, diantaranya: penyajian font, warna dan ilustrasi dalam buku pelajaran yang kurang menarik, belum ada animasi interaktif untuk membantu pemahaman materi, banyaknya hafalan dan cara penyampaian materi oleh guru yang monoton.

Tuntutan peserta didik dalam proses pembelajaran untuk mata pelajaran IPA adalah diperlukanya alternatif media pembelajaran selain buku pelajaran. Peserta didik belum dapat memahami materi IPA dengan baik apabila hanya menggunakan media pembelajaran buku cetak. Mata pelajaran IPA membutuhkan media pembelajaran yang harus disesuaikan de- 
ngan jenis pelajaran IPA itu sendiri. IPA bukan hanya sekedar sekumpulan pengetahuan tentang objek dan fenomena alam yang diperoleh dari hasil pemikiran dan penyelidikan ilmuwan yang dilakukan dengan keterampilan bereksperimen dengan menggunakan metode ilmiah (Kemendikbud, 2014, p.1), tetapi juga adanya gejalagejala alam yang bersifat abstrak. Untuk belajar IPA, tidak cukup menghafal materi pembelajaran tetapi harus mampu menjadi pebelajar mandiri sepanjang hayat. Metode pembelajaran dan sarana atau media yang belum sesuai akan berpengaruh pada tingkat kesukaran penyerapan materi ajar yang disampaikan oleh pendidik kepada peserta didik.

Media pembelajaran berbasis web merupakan salah satu layanan edukasi berbasis web yang memungkinkan terwujudnya edutainment dengan menggunakan media internet. Media pembelajaran berbasis web dapat menghubungkan pembelajaran antara pendidik dan peserta didik dalam sebuah ruang belajar online. Permasalahan pembelajaran konvensional dibandingkan dengan pembelajaran berbasis web dapat ditinjau dari segi interaktivitas pendidik dan peserta didik yang terbatas, fleksibilitas dalam hal penyediaan waktu, tempat dan bahan ajar serta aksebilitas sumber materi pembelajaran. Media pembelajaran berbasis web tercipta untuk mengatasi permasalahan-permasalahan tersebut. Pengembangan media pembelajaran berbasis web sangat tepat dilaksanakan karena dengan sistem pembelajaran yang melibatkan berbagai media (multimedia) seperti teks, gambar, audio, video, animasi dan e-book digital dalam pembelajaran, guru dapat menyajikan materi pelajaran yang lebih menarik, tidak monoton dan memudahkan penyampaian kepada peserta didik. Peserta didik mempunyai sumber belajar alternatif yang dapat digunakan untuk belajar mandiri dan membantu mereka untuk lebih memahami materi yang diajarkan. Maran, Selvaraj \& Ravikumar (2011, p.92) menyatakan bahwa penggunaan multimedia da- lam sumber belajar memberikan keuntungan bagi peserta didik dan pengajar. Pada penelitian tersebut jelas menunjukkan bahwa teknologi multimedia memiliki potensi besar untuk membantu belajar dan visualisasi pembelajaran siswa pada pemahaman konsep materi. Pembelajaran IPA berbasis web akan mempunyai kelebihan yang dapat memberikan fleksibilitas, interaktifitas, kecepatan dan visualisasi dalam proses pembelajaran. Lebih lanjut penelitian yang dilakukan di Wilfrid Laurier University (1998) Canada (Surjono, 1999, p.6) mengemukan bahwa peserta didik yang menggunakan web dalam pembelajarannya terbukti dua kali lebih cepat waktu belajarnya dibanding peserta didik klasikal, $80 \%$ peserta didik tersebut berprestasi baik dan amat baik, serta $66 \%$ dari mereka tidak memerlukan bahan cetak (hard copy). Disamping itu, penelitian yang dilakukan oleh Supriyono (2014, p.62) menunjukkan bahwa pengembangan media pembelajaran berbasis web layak digunakan dalam proses pembelajaran karena mampu meningkatkan rata-rata hasil belajar peserta didik dari $43 \%$ menjadi $86 \%$ dengan tingkat ketuntasan secara klasikal $4 \%$ menjadi $90 \%$ sehingga media pembelajaran berbasis web yang dikembangkan terbukti efektif dalam meningkatkan hasil belajar peserta didik.

Pembelajaran yang melibatkan semua indra peserta didik membuat pembelajaran menjadi lebih bermakna dan diharapkan mampu menjadi solusi terhadap permasalahan yang dihadapi guru dan peserta didik. Selain itu, proses pembelajaran tidak hanya terpaku di sekolah saja, peserta didik juga dapat mengakses media pembelajaran melalui komputer, smartphones maupun tablet diluar sekolah asalkan sudah terkoneksi dengan internet.

Media pembelajaran berbasis web diharapkan menjadi solusi pembelajaran untuk lebih memudahkan peserta didik dalam mencapai tujuan yang diinginkan. Karakteristik yang dimiliki media pembelajaran berbasis web seperti interaktivitas, fleksibilitas, aksebilitas dan pengayaan akan 
membuat masalah belajar yang dihadapi akan lebih mudah diatasi yang pada akhirnya akan berdampak positif terhadap peningkatan hasil belajar peserta didik. Melalui pengembangan media pembelajaran berbasis web, pengembang akan sekaligus memberikan solusi terhadap kebutuhan yang dihadapi peserta didik, pendidik dan sekolah. Pengembangan media pembelajaran berbasis web pada mata pelajaran Ilmu Pengetahuan Alam (IPA) dengan materi saling ketergantungan dalam ekosistem diharapkan dapat mengatasi keterbatasan dari ruang dan waktu yang dihadapi sekolah. Keindahan, kemenarikan, dan adanya interaktivitas dalam suatu media pembelajaran merupakan sarana agar siswa tidak jenuh dalam mengikuti pembelajaran. Efek terbesar yang diharapkan dengan adanya media pembelajaran berbasis web, siswa dapat termotivasi untuk lebih giat belajar, mempermudah siswa dalam memahami materi pelajaran dan mampu untuk meningkatkan hasil belajar siswa.

Berdasarkan uraian masalah dan solusi yang ditawarkan maka peneliti akan melaksanakan penelitian dan pengembangan media pembelajaran IPA berbasis web pada materi Saling Ketergantungan dalam Ekosistem bagi siswa kelas VII di SMP seKecamatan Depok Sleman meliputi SMP Muhammadiyah 2, SMPN 2, SMP N 3 dan SMPN 5 Depok Sleman.

Berdasarkan hasil identifikasi masalah dan solusi yang ditawarkan maka dirumuskan permasalahan yakni, (1) bagaimana penerapan media pembelajaran berbasis web pada mata pelajaran IPA bagi siswa kelas VII sebelum penelitian, (2) bagaimana merancang media pembelajaran berbasis web, (3) bagaimana media pembelajaran berbasis web hasil pengembangan, (4) bagaimana kelayakan media pembelajaran berbasis web, (5) bagaimana efektivitas media pembelajaran berbasis web pada mata pelajaran IPA bagi siswa kelas VII SMP se-Kecamatan Depok Sleman. Adapun tujuan penelitian ini adalah untuk menghasilkan produk berupa media pem- belajaran IPA berbasis web dan mengetahui tingkat kelayakan dan keefektifan media pembelajaran IPA berbasis web bagi siswa kelas VII SMP se-Kecamatan Depok Sleman. Melalui media pembelajaran IPA berbasis web ini diharapkan menjadi solusi terhadap masalah yang terindentifikasi.

Gagne dan Briggs (Arsyad, 2014, p.4) berpendapat bahwa media adalah segala alat fisik yang dapat menyajikan pesan serta merangsang siswa untuk belajar. Buku, film, kaset, film bingkai adalah contoh-contohnya. Media pembelajaran adalah komponen sumber belajar atau wahana fisik yang mengandung materi pembelajaran dilingkungan siswa yang dapat merangsang siswa untuk belajar.

Menurut Saputro (2007, p.1) website atau situs dapat diartikan sebagai kumpulan halaman yang menampilkan informasi data teks, data gambar diam atau bergerak, data animasi, suara, video dan atau gabungan dari semuanya, baik yang bersifat statis maupun dinamis yang membentuk satu rangkaian bangunan yang saling terkait dimana masing-masing dihubungkan dengan jaringan-jaringan halaman. Disamping itu, menurut Adelheid (2013, p.1) website adalah kumpulan dari halaman-halam situs yang terangkum dalam sebuah domain atau sub-domain yang tempatnya berada dalam world wide di dalam internet. Lebih lanjut, Arief (2011, pp.7-8) memaparkan bahwa Web adalah salah satu aplikasi yang berisikan dokumen-dokumen multimedia (teks, gambar, suara, animasi, video) didalamnya yang mengunakan protokol HTTP (hypertext transfer protocol) dan untuk mengaksesnya menggunakan perangkat lunak yang disebut browser.

Rusman (2012, p.291) mengatakan pembelajaran berbasis web merupakan suatu kegiatan pembelajaran yang memanfaatkan media situs (website) yang bisa diakses melalui jaringan internet. Pembelajaran berbasis web atau yang dikenal juga dengan "web based learning" merupakan salah satu jenis penerapan dari pembelajaran elektronik (e-learning). 
Menurut Rusman (2012, p.292), Pembelajaran berbasis web tidaklah sama dengan pembelajaran konvensional. Pembelajaran berbasis web memiliki karakteristik-karakteristik sebagai berikut: (1) interactivity (interaktivitas); tersedianya jalur komunikasi yang lebih banyak, baik secara langsung (synchronous), seperti chatting atau messenger atau tidak langsung (asynchronous) seperti forum, mailing list atau buku tamu. (2) Independency (Kemandirian); fleksibilitas dalam aspek penyediaan waktu, tempat, pengajaran dan bahan ajar. Hal ini menyebabkan pembelajaran menjadi lebih terpusat kepada siswa (studentcentered learning). (3) accessibility (aksesibilitas); sumber-sumber belajar menjadi lebih mudah diakses melalui pendistribusian di jaringan internet dengan akses yang lebih luas daripada pendistribusian sumber belajar pada pembelajaran konvensional. (4) enrichment (pengayaan); kegiatan pembelajaran, presentasi materi kuliah dan materi pelatihan sebagai pengayaan, memungkinkan penggunaan perangkat teknologi informasi seperti video streaming, simulasi dan animasi. Keempat karakteristik diatas merupakan hal yang membedakan pembelajaran berbasis web dengan kegiatan pembelajaran secara konvensional.

Rusman (2012, p.299) menyatakan bahwa sebagaimana media pembelajaran pada umumnya, pembelajaran berbasis web pun memiliki berbagai kelebihan yaitu: (1) memungkinkan setiap orang dimanapun, kapanpun, untuk mempelajari apapun; (2) pebelajar dapat belajar sesuai dengan karakteristik karena pembelajaran berbasis web membuat pembelajaran menjadi bersifat individu; (3) kemampuan untuk membuat tautan (link) sehingga pebelajar dapat mengakses informasi dari berbagai sumber, baik didalam maupun diluar lingkungan belajar; (4) sangat potensial sebagai sumber belajar bagi pebelajar yang tidak memiliki cukup waktu untuk belajar; (5) dapat mendorong pebelajar untuk lebih aktif dan mandiri didalam belajar; (6) menyediakan sumber belajar tambahan yang dapat digunakan untuk memperkaya materi pembelajaran. (7) menyediakan mesin pencari yang dapat digunakan untuk mencari informasi yang mereka butuhkan; (8) isi dari materi pelajaran dapat di-update dengan mudah.

Pemanfaatan media pembelajaran berbasis web juga tidak terlepas dari berbagai kekurangan. Adapun kelemahan media pembelajaran berbasis web menurut Cantillon, Jollie dan McKimm (2003, p.872) yaitu: (1) tersedianya peralatan komputer dapat menjadi masalah bagi siswa; (2) pembelajaran dapat merasa frustasi apabila mereka tidak dapat mengakses grafik, gambar dan video karena peralatan penunjang kurang memadai; (3) keakuratan dan kualitas informasi dapat berbeda sehingga bimbingan dari pengajar atau admin sangat dibutuhkan; (4) siswa dapat merasa lebih terisolasi.

Dalam pengembangan media pembelajaran IPA berbasis web tidak berbeda dengan pengembangan media pembelajaran lainnya, yaitu menggunakan teori pengembangan misalnya dari Brog \& Gall, Alessi \& Trollip, Rob Philips, Kemp, Criswell, Adrian Mallon, Lee \& Owens. Setelah dikaji berdasarkan pertimbangan proses pengembangan, jumlah subjek uji coba yang terlibat, waktu serta efisiensi untuk penelitian berskala kecil dan khususnya pada langkah evaluasi produk, maka dalam penelitian ini dipilih model penelitian dan pengembangan dari Borg \& Gall (1983, p.775) dan Alessi \& Trollip (2001, p.410).

Langkah-langkah yang dilakukan dalam penelitian pengembangan Borg \& Gall (1983, p.775) pada media pembelajaran berbasis web ini meliputi sepuluh langkah yaitu: (1) Penelitian pendahuluan dan pengumpulan informasi (research and information collecting); (2) perencanaan (planning); (3) mengembangkan produk awal (Develop preliminary form of product); (4) uji coba lapangan awal (Preliminary field testing); (5) revisi terhadap produk utama (Main product revision); (6) uji lapangan utama (Main field testing); (7) revisi produk uji coba lapangan (Operational product revi- 
sion); (8) uji lapangan operasional (Operational field testing); (9) revisi terhadap produk akhir (Final product revision); (10) mendeseminasikan dan mengimplementasikan produk (Dissemination and implementation).

Model pengembangan dalam penelitian ini menggunakan model yang dikembangkan oleh Alessi \& Trollip (2001, pp.409-410) memiliki tiga atribut (three attributes) dan tiga fase (three phases). Tiga atribut tersebut adalah standar, ongoing evaluation dan project management. Sedangkan tiga fase pengembangan yaitu perencanaan (planning), desain (design) dan pengembangan (development).

Alessi \& Trollip (2001, p.548) juga mengemukakan beberapa aspek yang penting untuk dinilai pada media pembelajaran berbasis web. Adapun aspek-aspek tersebut yakni, (1) subject matter (pelajaran), (2) auxiliary information (informasi pendukung), (3) affective consideration (pertimbangan sikap), (4) interface (komunikasi pengguna terhadap program), (5) navigation (navigasi), (6) pedagogy (aktifitas belajar), (7) invisible feature (fitur yang sukar diamati), (8) robustness (kehandalan), (9) supplementary materials (material pengayaan).

Masalah pokok yang dihadapi dunia pendidikan selama ini adalah mengenai peningkatan mutu pendidikan dengan tantangan kemajuan zaman. Kenyataan demikian menunjukkan bahwa pemecahan masalah pendidikan kita membutuhkan alternatif baru yang disesuaikan dengan kemajuan zaman. Surjono (2012, p.1) mengemukakan bahwa guru dituntut dapat mengimplementasikan Teknologi Informasi dan Komunikasi atau ICT secara optimal untuk memfasilitasi aktivitas pembelajaran yang mendorong pengembangan skill dan pengetahuan siswa. Namun, memang tidak mudah bagi guru dan siswa untuk dapat memanfaatkan ICT secara optimal dalam pembelajaran. Paling tidak ada tiga kondisi yang harus dipenuhi, yakni: (1) guru dan siswa harus mempunyai akses yang mudah ke perangkat teknologi ter- masuk koneksi internet, (2) tersedianya konten digital (bahan ajar) yang mudah dipahami guru dan siswa, (3) guru harus punya pengetahuan dan keterampilan menggunakan teknologi dan sumber daya guna membantu siswa mencapai standar akademik.

Media pembelajaran web atau elearning yang kini menjadi sangat populer karena fleksibilitas dan efektivitasnya merupakan cara penyampaian materi pembelajaran melalui internet. Melalui media pembelajaran web materi pembelajaran dapat diakses kapan saja dan dari mana saja. Disamping itu karena materi dapat diperkaya dengan berbagai sumber belajar termasuk multimedia dan dengan cepat dapat diperbaharui oleh guru, maka pembelajaran IPA dapat juga memanfaatkan keunggulan media pembelajaran web ini untuk meningkatkan mutu pembelajaran.

Berbagai potensi yang dimiliki media pembelajaran web dimungkinkan dijadikan sebagai suatu alternatif dalam pemecahan permasalahan dalam pembelajaran dan dapat dimanfaatkan untuk meningkatkan mutu pembelajaran IPA. Banyak faktor yang berpengaruh atau mendukung terwujudnya proses pembelajaran yang berkualitas dalam upaya mencapai tujuan pendidikan, salah satu di antaranya adalah penggunaan atau pemanfaatan teknologi dalam proses pendidikan dan pembelajaran (Miarso, 2005, p.121).

Siahaan (Ismaniati, 2012, p.9) mengemukakan bahwa pentingnya pemanfaatan media pembelajaran web dalam pembelajaran mengingat potensi media pembelajaran web ini dalam memfasilitasi dan mengoptimalkan proses belajar siswa dalam meningkatkan mutu pembelajaran antara lain: (1) membuat konkrit konsep yang abstrak, misalnya untuk menjelaskan sistem peredaran darah; (2) membawa objek yang berbahaya atau sukar didapat ke dalam lingkungan belajar, seperti: binatang-binatang buas, atau penguin dari kutub selatan; (3) menampilkan objek yang terlalu besar, seperti pasar, candi borobudur; (4) menampilkan objek yang tidak 
dapat dilihat dengan mata telanjang, seperti: mikro organisme; (5) mengamati gerakan yang terlalu cepat, misalnya dengan slow motion atau time-lapse photograhy; (6) memungkinkan siswa berinteraksi langsung dengan lingkungannya; (7) memungkinkan keseragaman pengamatan dan persepsi bagi pengalaman belajar siswa; (8) membangkitkan motivasi belajar siswa; (9) menyajikan informasi belajar secara konsisten, akurat, berkualitas dan dapat diulang penggunaannya atau disimpan sesuai dengan kebutuhan; atau (10) menyajikan pesan belajar secara serempak untuk lingkup sasaran yang sedikit/kecil atau banyak/ luas, mengatasi batasan waktu (kapan saja) maupun ruang di mana saja). Dalam konteks yang lebih luas, yaitu pendidikan pada mata pelajaran IPA, potensi media pembelajaran web yang tampak jelas setidaknya adalah memperluas kesempatan belajar, meningkatkan kualitas dan efisiensi belajar, memungkinkan terjadinya belajar mandiri dan belajar kooperatif, serta mendorong terwujudnya belajar sepanjang hayat.

Menurut Ally, Janicki dan Liegle (Surjono, 2013, p.7), untuk mengembangkan materi pembelajaran dalam e-learning atau media pembelajaran berbasis web perlu mempertimbangkan tiga teori belajar yang sangat terkenal yaitu: behaviorisme, kognitivisme dan konstruktivisme. Surjono (2013, pp.7-8) menyatakan bahwa ada beberapa contoh implementasi prinsip behaviorisme dalam e-learning atau media pembelajaran berbasis web diantaranya: (1) tujuan pembelajaran perlu ditampilkan, (2) pencapaian belajar perlu dinilai, (3) materi harus runtut mulai dari sederhana hingga kompleks, (4) umpan balik perlu diberikan. Surjono (2013, p.8) menambahkan contoh implementasi prinsip kognitivisme dalam $e$ learning atau media pembelajaran berbasis web diantaranya: (1) informasi yang penting perlu diletakkan ditengah layar; (2) informasi yang penting perlu ditonjolkan untuk menarik perhatian; (3) informasi perlu ditampilkan sedikit demi sedikit untuk menghindari terjadinya beban pada memori; (4) materi pembelajaran perlu disajikan sesuai dengan gaya belajar peserta didik. Lebih lanjut menurut Surjono (2013, p.8), ada beberapa contoh implementasi prinsip konstruktivisme dalam e-learning atau media pembelajaran berbasis web diantaranya: (1) program e-learing atau media pembelajaran web perlu bersifat interaktif; (2) contoh dan latihan perlu bermakna; (3) peserta didik dapat mengontrol jalannya pembelajaran.

\section{Metode Penelitian}

Penelitian ini merupakan penelitian pengembangan atau dikenal dengan istilah Research and Development (R\&D) yang meng-hasilkan sebuah produk berupa media pembelajaran berbasis web pada mata pelajaran Ilmu Pengetahuan Alam (IPA) bagi siswa kelas VII SMP se-Kecamatan Depok Sleman. Waktu penelitian dimulai dari bulan Maret hingga Juni 2015. Lokasi penelitian atau uji coba produk yakni di Laboratorium Komputer SMP se-Kecamatan Depok Sleman. Pada pelaksanaannya uji coba dilakukan sebanyak satu kali pertemuan.

Target/sasaran penelitian dan uji coba produk yakni siswa kelas VII SMP seKecamatan Depok Sleman. Subjek atau responden yang terlibat dalam penelitian ini adalah siswa kelas VII SMP se-Kecamatan Depok Sleman. Penetapan subjek berdasarkan pertimbangan bahwa materi yang diajarkan sesuai dengan analisis kebutuhan dan pelajaran pada semester II. Untuk lebih jelasnya subjek uji coba sebagai berikut: (1) subjek untuk analisis kebutuhan terdiri dari 60 orang siswa kelas VII SMP se-Kecamatan Depok Sleman, (2) Subjek untuk uji coba test alpha dilakukan oleh ahli media dan ahli materi yang terdiri dari 2 ahli media dan 2 ahli materi dengan dasar pertimbangan bahwa ahli media dan materi tidak berkeberatan, berkompeten dibidangnya dan bersedia menilai instrumen. Ahli materi terdiri dari 1 dosen dan 1 guru mata pelajaran IPA, (3) subjek ujicoba tes beta dilakukan oleh 12 orang siswa 
kelas VII SMP se-Kecamatan Depok Sleman yang dipilih secara acak dengan dasar pertimbangan tidak menggangu proses pembelajaran dan bersedia dalam menguji produk, dan (4) Subjek dalam penilaian evaluasi sumatif (produk akhir) melibatkan 116 orang siswa kelas VII SMP se-Kecamatan Depok Sleman.

Model penelitian R\&D yang digunakan oleh peneliti adalah model penelitian Borg \& Gall (1983, p.775), sedangkan model pengembangan media pembelajaran menggunakan model yang dikembangkan oleh Alessi \& Trollip (2001, p.410) yang kemudian oleh peneliti disesuaikan dengan kemampuan dan keterbatasan penelitian. Sebelum melakukan pengembangan untuk menentukan karakteristik materi dan karakteristik pengguna, peneliti telah melakukan analisis kebutuhan terlebih dahulu kepada guru dan siswa.

Model pengembangan dan desain multimedi yang dikembangkan oleh Alessi \& Trollip (2001, pp.409-410) memiliki tiga atribut (three attributes) dan tiga fase (three phases), tiga atribut tersebut meliputi standard, ongoing evaluation, dan project management. Sedangkan tiga fase meliputi perencanaan (planning), desain (design) dan pengembangan (development).

Data yang diperoleh dalam penelitian ini merupakan data kualitatif dan kuantitatif. Data kuantitatif diperoleh dari hasil validasi yang dilakukan oleh ahli media dan ahli materi (uji coba alpha) serta data dari pengguna (uji coba beta dan uji coba produk). Sedangkan data kualitatif didapat dari hasil analisis kebutuhan, saran ahli media dan ahli materi serta pendapat dan tanggapan pengguna yang digunakan dalam pengembangan produk. Data-data tersebut dibutuhkan agar nantinya dapat memberikan gambaran mengenai kelayakan media pembelajaran berbasis web dan kualitas teknik tampilan produk serta peningkatan pemahaman siswa setelah menggunakan produk media pembelajaran berbasis web.

Instrumen yang digunakan untuk memperoleh data pokok sesuai tujuan penelitian adalah instrumen kuesioner dan uji kompetensi hasil belajar. Data berupa instrumen kuesioner dan uji kompetensi tersebut menggambarkan secara rinci kualitas media pembelajaran web sebagai media serta tujuan materi pembelajaran. Lembar penilaian disusun berdasarkan indikator-indikator kualitas media dari Alessi \& Trollip (2001, p.414) dan desain kualitas materi dari Dick \& Carey (2009, pp.218219). Instrumen yang digunakan untuk penelitian terlebih dahulu dilakukan validasi oleh ahli instrumen.

Validasi instrument meliputi penentuan expert judgement ahli media, ahli materi, dan siswa. Instrumen penelitian diukur tingkat validitas dan reliabilitasnya sebelum digunakan untuk menjaring data. Hal ini bertujuan untuk mendapatkan kualitas instrumen penelitian yang baik. Validasi instrumen dilakukan melalui konsultasi pembimbing dan seorang validator instrumen.

Data angket guru dan siswa hasil analisis kebutuhan yang diperoleh pada saat prasurvey digunakan sebagai dasar untuk menentukan ide awal pengembangan media pembelajaran berbasis web pada mata pelajaran IPA. Selain itu saran dari ahli media, ahli materi, dan siswa dihimpun dan dianalisis untuk memperbaiki media pembelajaran berbasis web pada mata pelajaran IPA.

Tabel 1. Kriteria Penilaian Kelayakan Media Pembelajaran Web (Sukardjo, 2006, p.53)

\begin{tabular}{|c|c|c|c|}
\hline \multirow[t]{2}{*}{ Nilai } & \multirow[t]{2}{*}{ Kriteria } & \multicolumn{2}{|l|}{ Skor } \\
\hline & & Rumus & Perhitungan \\
\hline A & $\begin{array}{c}\text { Sangat } \\
\text { Baik }\end{array}$ & $X>X i+1,8 S b i$ & $X>4,21$ \\
\hline B & Baik & $X i+0,6 S b i<X \leq X i+1,8 S b i$ & $3,40<X \leq 4,21$ \\
\hline C & Cukup & $X i-0,6 S b i<X \leq X i+0,6 S b i$ & $2,60<X \leq 3,40$ \\
\hline $\mathrm{D}$ & Kurang & $X i-1,8 S b i<X \leq X i-0,6 S b i$ & $1,79<X \leq 2,60$ \\
\hline $\mathrm{E}$ & $\begin{array}{l}\text { Sangat } \\
\text { Kurang }\end{array}$ & $X \leq X i-1,8 S b i$ & $X \leq 1,79$ \\
\hline
\end{tabular}

Data yang diperoleh dari validasi ahli media, materi, dan tanggapan siswa dianalisis menggunakan statistik deskriptif 
kemudian dikonversi ke dalam data " 5 " (Sukardjo, 2006, p.53). Konversi data untuk menentukan kategori penilaian disajikan pada Tabel 1.

\section{Hasil Penelitian dan Pembahasan}

Hasil pengembangan produk media pembelajaran berbasis web mata mata pelajaran IPA bagi siswa kelas VII SMP seKecamatan Depok Sleman berhasil dikembangkan menggunakan CMS (Content Management System) Wordpress dan digunakan dalam proses pembelajaran IPA secara online. Pengguna dapat mengakses media pembelajaran web ini melalui alamat URL http://ipa.ewin.web.id. Berikut tampilan media pembelajaran berbasis web yang dapat dilihat melalui Gambar 3 dan 4.

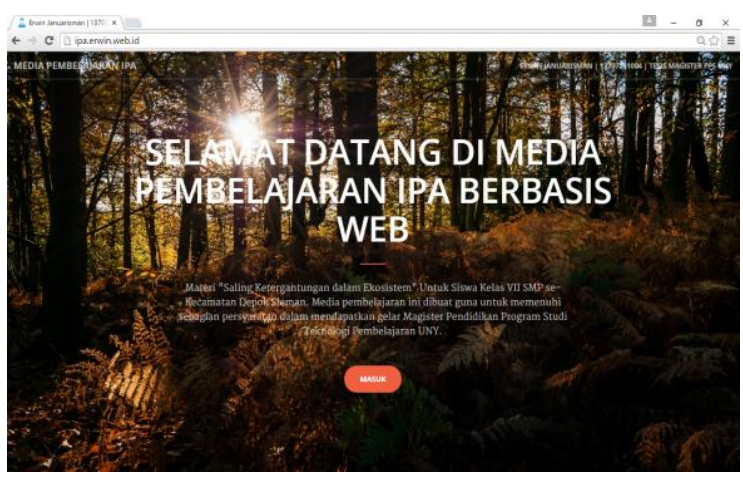

Gambar 3. Tampilan Halaman Pembuka Belajar IPA
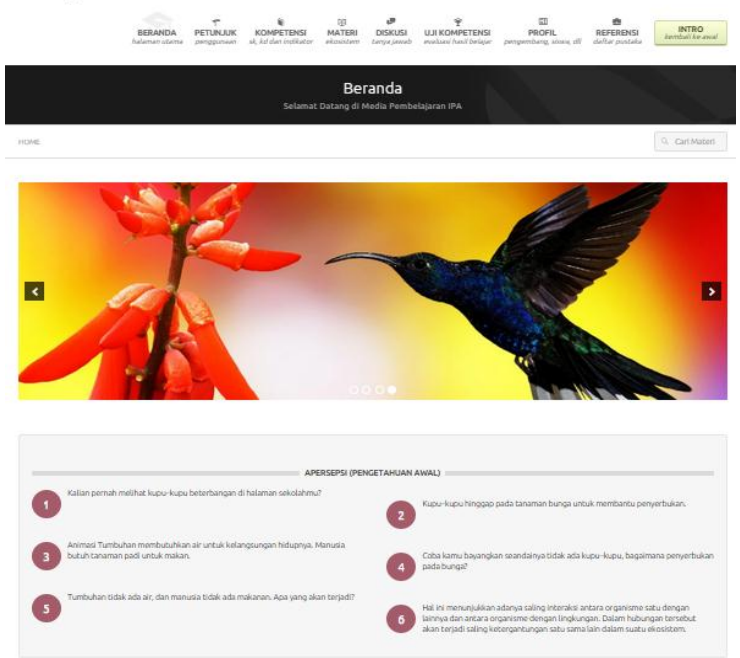

Gambar 4. Tampilan Halaman Beranda

Kelayakan hasil pengembangan produk media pembelajaran IPA berbasis web dapat diketahui melalui hasil evaluasi formatif produk media pembelajaran berbasis web berdasarkan model pengembangan Alessi \& Trollip (2001, pp.548-553). Tahap evaluasi formatif meliputi uji alpha dan uji beta yang bertujuan untuk mengetahui tingkat kualitas kelayakan media pembelajaran IPA berbasis web yang telah dikembangkan. Uji alpha dilakukan masing-masing oleh 2 orang ahli media dan 2 orang ahli materi, sedangkan uji beta dilakukan oleh 3 orang dari masing-masing sekolah sehingga berjumlah 12 orang.

Tabel 2. Distribusi Frekuensi Hasil Penilaian Dua Ahli Materi

\begin{tabular}{|c|c|c|c|c|c|c|}
\hline \multirow[t]{2}{*}{ No } & \multirow[t]{2}{*}{ Interval } & \multirow[t]{2}{*}{ Kriteria } & \multicolumn{2}{|c|}{ Ahli Materi 1} & \multicolumn{2}{|c|}{ Ahli Materi 2} \\
\hline & & & F & $\%$ & F & $\%$ \\
\hline 1 & $5>4,22$ & $\begin{array}{c}\text { Sangat } \\
\text { Baik }\end{array}$ & 0 & 0 & 9 & 226,5 \\
\hline 2 & $4,21-3,41$ & Baik & 25 & 73,5 & 24 & 70,6 \\
\hline 3 & $3,40-2,61$ & Cukup & 9 & 26,5 & 1 & 2,9 \\
\hline 4 & $2,60-1,80$ & Kurang & 0 & 0 & 0 & 0 \\
\hline \multirow[t]{2}{*}{5} & $<1,80$ & $\begin{array}{l}\text { Sangat } \\
\text { Kurang }\end{array}$ & 0 & 0 & 0 & 0 \\
\hline & Jumlah & & 34 & 100 & 34 & 100 \\
\hline
\end{tabular}

Keterangan : frekuensi (F) \& persentase (\%)

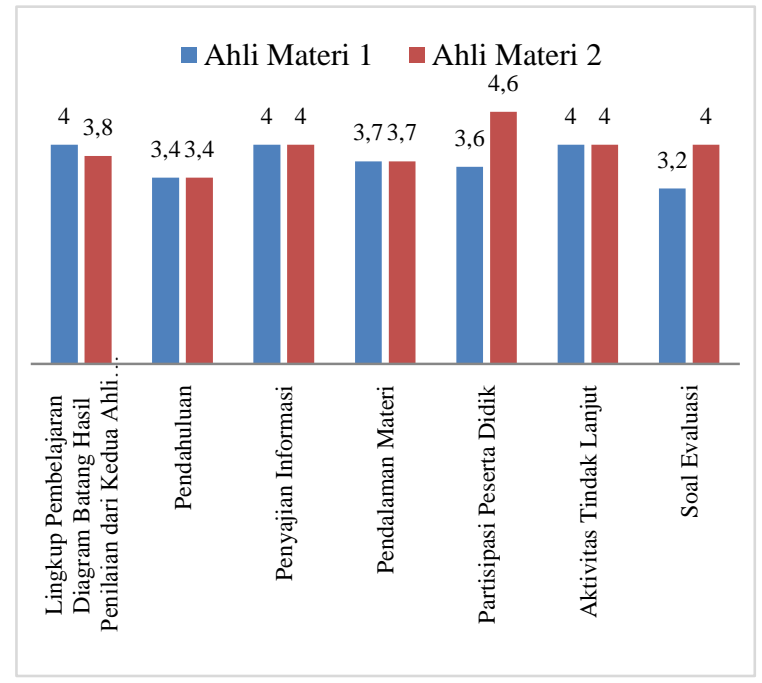

Gambar 5. Diagram Batang Hasil Penilaian Dari Kedua Ahli Materi

Validasi yang dilakukan oleh kedua ahli materi meliputi beberapa aspek diantaranya: lingkup pembelajaran, pendahuluan, penyajian informasi, pendalaman materi, partisipasi peserta didik, aktivitas 
tindak lanjut dan soal evaluasi. Data yang diperoleh kemudian dianalisis dengan cara mengkonversi ke dalam skala 5. Hasil olah data dari validasi dua ahli materi dapat diketahui kualitas materi pembelajaran yang di-upload di media pembelajaran IPA berbasis web memiliki kriteria "baik" dan "sangat baik" dengan rata-rata penilaian 3,73 dan 4,23 . Penilaian dua ahli materi dapat dilihat pada Tabel 2.

Secara visual hasil penilaian atau hasil validasi dari dua ahli materi pada uji alpha dapat dilihat pada Gambar 5.

Hasil validasi dari 2 orang ahli media terhadap kualitas kelayakan media pembelajaran IPA berbasis web pada uji alpha ditinjau dari beberapa aspek diantaranya: informasi tambahan (auxiliary information), pertimbangan sikap pengguna (affective considerations), hubungan pengguna dengan program (interface), teknik perpindahan halaman (navigasi), pedagogi (pedagogy), fitur tak tampak (invisible features) dan kehandalan program (robustness). Aspek yang dikaji sebanyak 7 aspek yang terdiri dari 34 indikator.

Tabel 3. Distribusi Frekuensi Penilaian oleh Dua Ahli Media

\begin{tabular}{ccccccc}
\hline No & Interval & Kriteria & \multicolumn{3}{c}{ Ahli Materi 1 } & \multicolumn{3}{c}{ Ahli Materi 2 } \\
& & & F & $\%$ & F & $\%$ \\
\hline 1 & $5>4,22$ & Sangat & 2 & 5,9 & 5 & 14,7 \\
2 & $4,21-3,41$ & Baik & & & & \\
3 & $3,40-2,61$ & Cukup & 0 & 0 & 7 & 20,6 \\
4 & $2,60-1,80$ & Kurang & 0 & 0 & 0 & 0 \\
5 & $<1,80$ & Sangat & 0 & 0 & 0 & 0 \\
& Jumlah & & 34 & 100 & 34 & 100 \\
\hline
\end{tabular}

Keterangan : frekuensi (F) \& persentase (\%)

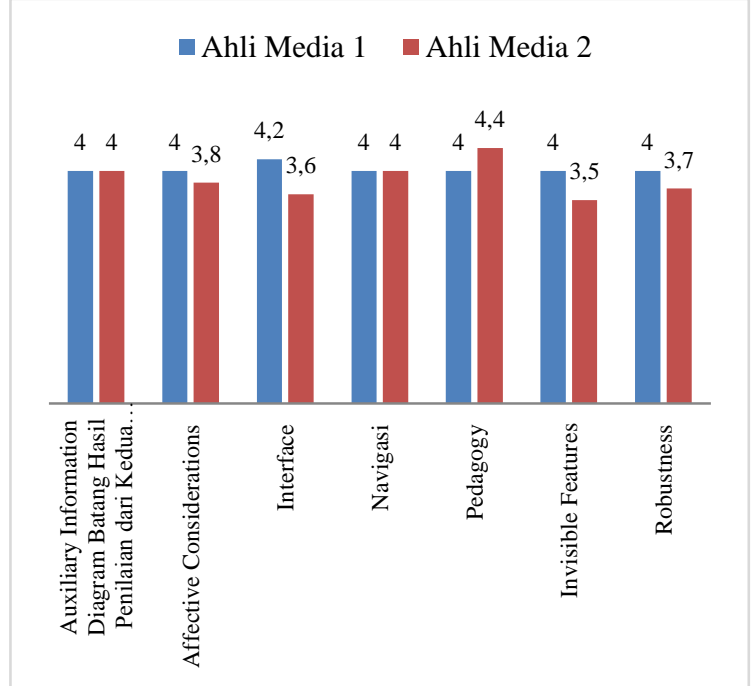

Gambar 6. Diagram Batang Hasil Penilaian Dari Kedua Ahli Media

Data yang diperoleh dari hasil validasi oleh kedua ahli media selanjutnya dikonversikan ke dalam skala 5. Hasil data dari validasi dua ahli media dapat diketahui kualitas kelayakan media termasuk dalam kategori "baik" dengan rata-rata 4,21 dan 3,93. Hasil analisis data penilaian oleh kedua ahli media dapat dilihat pada Tabel 3.

Secara visual hasil penilaian atau hasil validasi dari dua ahli media pada uji alpha dapat dilihat pada Gambar 6 .

Uji beta dilakukan untuk mengetahui kualitas media pembelajaran IPA berbasis web dari sudut pandang calon pengguna atau subjek uji coba. Peserta yang melakukan uji beta terdiri dari 3 orang kelas VII dari masing-masing sekolah sehingga berjumlah 12 orang. Hasil analisis data uji beta dapat diketahui melalui Tabel 4 .

Tabel 4. Distribusi Frekuensi Hasil Uji Beta

\begin{tabular}{|c|c|c|c|c|c|c|c|c|c|c|c|c|c|c|c|}
\hline \multirow{2}{*}{ No } & \multirow{2}{*}{ Kriteria } & \multicolumn{14}{|c|}{ Peniliaian } \\
\hline & & F1 & $\mathrm{F} 2$ & F3 & F4 & F5 & F6 & F7 & F8 & F9 & F10 & F11 & F12 & $\sum \mathrm{F}$ & $\%$ \\
\hline 1 & Sangat Baik & 14 & 11 & 9 & 13 & 14 & 4 & 17 & 19 & 7 & 17 & 6 & 23 & 154 & 35,65 \\
\hline 2 & Baik & 12 & 17 & 23 & 18 & 17 & 23 & 16 & 16 & 16 & 18 & 23 & 8 & 207 & 47,92 \\
\hline 3 & Cukup & 10 & 6 & 3 & 4 & 4 & 8 & 2 & 0 & 13 & 1 & 6 & 5 & 62 & 14,35 \\
\hline 4 & Kurang & 0 & 1 & 1 & 1 & 1 & 1 & 1 & 1 & 0 & 0 & 1 & 0 & 8 & 1,85 \\
\hline 5 & Sangat Kurang & 0 & 1 & 0 & 0 & 0 & 0 & 0 & 0 & 0 & 0 & 0 & 0 & 1 & 0,23 \\
\hline
\end{tabular}

Keterangan : Frekuensi (F1-F2), Total frekuensi ( $\sum$ F) dan Persentase (\%) 
Berdasarkan hasil rekapitulasi data uji beta terhadap media pembelajaran IPA berbasis web diperoleh rata-rata penilaian 4,13. Hasil analisis terhadap data dan persentase hasil penilaian subjek coba pada uji beta diketahui bahwa kualitas media pembelajaran berbasis web pada mata pelajaran IPA bagi siswa kelas VII SMP seKecamatan Depok Sleman termasuk dalam kategori baik dan layak untuk digunakan pada proses pembelajaran.

Efektivitas media pembelajaran berbasis web dapat diketahui melalui hasil evaluasi sumatif produk media pembelajaran berbasis web berdasarkan model pengembangan Alessi \& Trollip (2001, pp.553-557). Evaluasi sumatif dilaksanakan secara formal, hal ini untuk mengetahui apakah media pembelajaran web yang telah dikembangkan sudah efektif untuk mencapai tujuan yang telah ditetapkan yakni untuk meningkatkan hasil belajar atau kompetensi peserta didik. Evaluasi sumatif dilaksanakan di Laboratorium Komputer Sekolah. Evaluasi sumatif media pembelajaran web di SMP Muhammadiyah 2 Depok Sleman dilaksanakan pada hari Sabtu tanggal 30 Mei 2015. Evaluasi sumatif media pembelajaran web di SMP N 2 Depok Sleman dilaksanakan pada hari Rabu tanggal 03 Juni 2015, Evaluasi sumatif media pembelajaran web di SMP N 3 Depok Sleman dilaksanakan pada hari Kamis tanggal 04 Juni 2015 dan Evaluasi sumatif media pembelajaran web di SMP N 5 Depok Sleman dilaksanakan pada hari Sabtu tanggal 06 Juni 2015.

Pengukuran hasil uji kompetensi kognitif peserta didik dilakukan untuk me- ngetahui hasil belajar siswa menggunakan dua cara yaitu: (1) melalui pemberian pretest dan posttest dengan melihat kenaikan nilai gain; dan (2) melihat perbandingan atau uji rata-rata menggunakan uji $t$ (paired sample t-test). Pada evaluasi sumatif ini, peserta didik dari SMP Muhammadiyah 2 Depok berjumlah 21 orang, peserta didik dari SMP N 2 Depok berjumlah 32 orang, peserta didik dari SMP N 3 Depok berjumlah 32 orang dan peserta didik dari SMP N 5 Depok berjumlah 31 orang sehingga keseluruhan peserta didik pada evaluasi sumatif ini berjumlah 116 orang. Adapun hasil belajar siswa dalam bentuk uji kompetensi diperoleh melalui pretest dan posttest yang dapat dilihat pada Tabel 5 .

Berdasarkan Tabel 5 dapat diperoleh: (1) SMP Muhammadiyah 2 Depok memperoleh rata-rata pretest 62,38 dan rata-rata posttest 84,52 . Setelah dianalisa terdapat peningkatan nilai rata-rata (gain) sebesar 22,14; (2) SMP N 2 Depok memperoleh rata-rata pretest 62,03 dan rata-rata posttest 86,09. Setelah dianalisa terdapat peningkatan nilai rata-rata (gain) sebesar 24,06; (3) SMP N 3 Depok memperoleh rata-rata pretest 62,65 dan rata-rata posttest 84,06 . Setelah dianalisa terdapat peningkatan nilai rata-rata (gain) sebesar 21,41; (4) SMP N 5 Depok memperoleh rata-rata pretest 65,80 dan rata-rata posttest 85,48 . Setelah dianalisa terdapat peningkatan nilai rata-rata (gain) sebesar 19,68. Data hasil belajar ini menjadi rekomendasi bagi pengembang untuk menyimpulkan bahwa media pembelajaran IPA berbasis web dapat meningkatkan hasil belajar siswa.

Tabel 5. Data Hasil Belajar Siswa (Pretest dan Posttest)

\begin{tabular}{cccccccccc}
\hline \multirow{2}{*}{ No } & \multirow{2}{*}{ Variabel } & \multicolumn{2}{c}{ SMP Muh 2 } & \multicolumn{2}{c}{ SMP N 2 } & \multicolumn{2}{c}{ SMP N 3 } & \multicolumn{2}{c}{ SMP N 5 } \\
& & Pre & Post & Pre & Post & Pre & Post & Pre & Post \\
\hline 1 & Nilai tertinggi & 80 & 100 & 80 & 100 & 80 & 100 & 80 & 100 \\
2 & Nilai terendah & 35 & 75 & 35 & 60 & 30 & 65 & 45 & 70 \\
3 & Jumlah & 1310 & 1775 & 1985 & 2755 & 2005 & 2690 & 2040 & 2650 \\
4 & Rata-rata & 62,38 & 84,52 & 62,03 & 86,09 & 62,65 & 84,06 & 65,80 & 85,48 \\
5 & Gain & \multicolumn{2}{c}{22,14} & 24,06 & 21,41 & \multicolumn{2}{c}{19,68} \\
\hline
\end{tabular}


Evaluasi sumatif hasil belajar siswa diujicobakan pada siswa kelas VII yang dilakukan melalui uji pretest dan posttest. Data hasil pretest dan posttest kemudian dibandingkan untuk mengetahui perbandingan antara nilai tertinggi, nilai terendah, rata-rata dan selisih posttest-pretest (gain) sebelum menggunakan media pembelajaran web dan sesudah menggunakan media pembelajaran web. Nilai gain menunjukkan peningkatan pemahaman atau penguasaan konsep siswa setelah pembelajaran dilakukan. Adapun perbandingan hasil uji kompetensi dapat dilihat pada Gambar 7.

Berdasarkan Gambar 7 hasil penilaian evaluasi sumatif media pembelajaran web dapat diketahui beberapa hal sebagai berikut: (1) Nilai tertinggi mata pelajaran IPA di semua sekolah sebesar 100; (2) Nilai rata-rata untuk posttest di SMP Muh 2 sebesar 84.5, nilai rata-rata untuk posttest di SMP N 2 sebesar 86, nilai rata-rata untuk posttest di SMP N 3 sebesar 84 dan nilai rata-rata untuk posttest di SMP N 5 sebesar 85.4; (3) Selisih nilai gain (posttest-pretest) untuk tingkat efektivitas pada sekolah SMP Muh 2 sebesar 22.2, nilai gain di SMP N 2 sebesar 24, nilai gain di SMP N 3 sebesar 21,6 dan Gain di SMP N 5 sebesar 19,6; (4) Nilai Gain terbesar dari SMP N 2 Depok sebesar 24 disusul SMP Muhammadiyah 2 Depok sebesar 22,2 dan SMP N 3 sebesar 21,6 serta nilai gain terkecil dari SMP N 5 Depok Sleman sebesar 19,6.

Hasil analisis uji $t$ paired sample $t$ test (Tabel 6) terlihat bahwa $t$ hitung adalah -37.679 dengan probabilitas 0,000 oleh karena probabilitas $<0,05$ maka kedua rata-rata populasi adalah tidak identik (rata-rata nilai pretest dan posttest berbeda secara nyata).

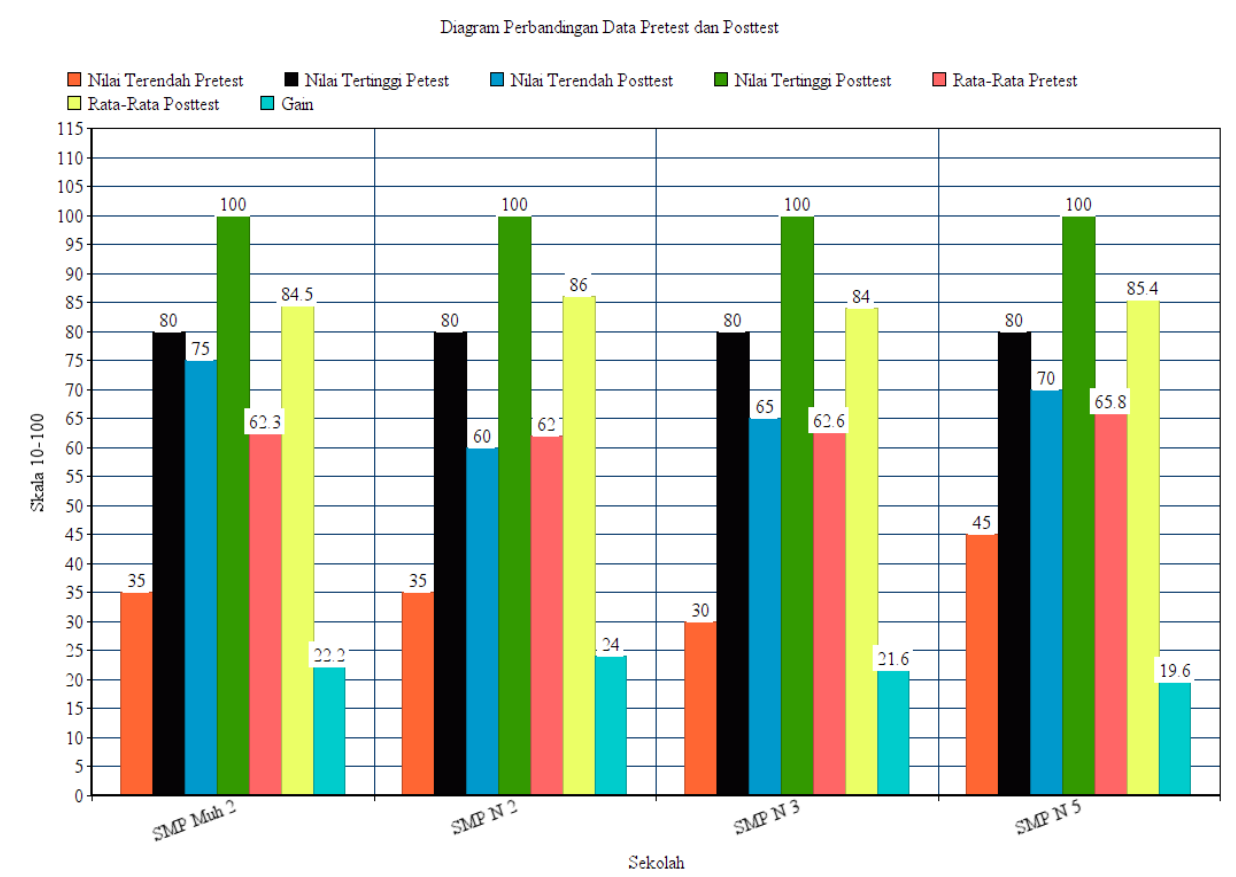

Gambar 7. Diagram Perbandingan Data Pretest, Posttest, Rata-Rata dan Gain

Tabel 6. Uji Paired Sample $t$-test Pretest-Posttest

Paired Sampel Test

\begin{tabular}{lcccccc}
\hline & & \multicolumn{4}{c}{ Paired Difference } \\
& Mean & Std. & Std. Error & \multicolumn{2}{c}{ 95\% Confidence Interval of } & the Difference \\
& Deviation & Mean & Lower & Upper & \\
\hline Pair 1 Pretest-Posttest & -21.810 & 6.234 & .579 & -22.957 & -20.664 & -37.679 \\
\hline
\end{tabular}


Berdasarkan data Gambar 7 dan Tabel 6 peningkatan kompetensi peserta didik terhadap pemahaman konsep dengan membandingkan nilai pretest dan posttest serta analisis uji $t$ menunjukkan nilai pretest lebih rendah jika dibandingkan dengan nilai posttest. Efek postitif menggunakan media pembelajaran IPA secara online dalam pembelajaran dapat meningkatkan kompetensi peserta didik, hal ini terbukti dengan melihat hasil nilai pretest dan posttest setelah pembelajaran, sehingga pembelajaran menggunakan media pembelajaran IPA berbasis web dapat meningkatkan kompetensi kognitif atau pemahaman konsep materi IPA pada peserta didik.

Adapun keterbatasan dalam penelitian ini: (1) materi pelajaran yang ada di media pembelajaran IPA berbasis web ini baru sebatas pada materi "Saling Ketergantungan dalam Ekosistem"; (2) jumlah lokasi penelitian yang terbatas, dari total 10 SMP Negeri dan Swasta yang ada di Kecamatan Depok Sleman, peneliti hanya bisa melakukan penelitian pada 4 lokasi yakni di SMP Muhammadiyah 2 Depok, SMP N 2, SMP N 3 dan SMPN 5 Depok Sleman, hal ini disebabkan karena keterbatasan biaya, waktu, jarak dan tenaga dari peneliti; (3) penerapan media pembelajaran IPA berbasis web dalam pembelajaran akan lebih efektif jika dilaksanakan dengan pertemuan pembelajaran lebih banyak, minimal tiga kali pertemuan. Namun, dalam penelitian dan pengembangan ini peneliti mengalami kesulitan dalam mengatur alokasi waktu pembelajaran karena masa studi peneliti dan keterbatasan waktu di sekolah yang akan melaksanakan ujian akhir sekolah (UAS); (4) subjek uji coba dalam penelitian dan pengembangan yang terbatas, menyebabkan tidak semua siswa di SMP se-Kecamatan Depok Sleman dapat diuji coba, (5) kecepatan koneksi internet di Sekolah kadang tidak stabil sehingga berpengaruh pada kecepatan akses media pembelajaran web.

Keterbatasan dalam pengembangan media pembelajaran IPA berbasis web ini diantaranya: (1) pengembangan media pembelajaran IPA berbasis web ini bisa dimanfaatkan untuk membaca materi pelajaran, menjawab soal, mengirimkan pesan ke guru namun belum bisa digunakan untuk melihat report performa belajar teman sekelas; (2) belum tersedia sistem penilaian (rating) pada materi-materi yang disediakan. Setelah menyelesaikan 1 menu materi, siswa belum bisa menilai materi tersebut, dan memberikan masukan apapun yang ingin disampaikan terhadap materi yang sudah dipelajari; (3) Media pembelajaran berbasis web ini belum support Live Broadcast Video / Video Conference dan login menggunakan akun sosial media. (4) media pembelajaan IPA berbasis web ini akan melakukan loading tiap akan berpindah halaman, media pembelajaran web ini akan lebih optimal apabila loading web hanya sekali pada saat pertamakali mengakses media pembelajaran web.

\section{Simpulan dan Saran}

Simpulan

Berdasarkan hasil analisis data dan kajian produk hasil pengembangan dapat disimpulkan sebagai berikut. Pertama, penerapan media pembelajaran berbasis web pada mata pelajaran IPA bagi siswa kelas VII sebelum dilakukan penelitian berdasarkan hasil survey menunjukkan bahwa SMP se-Kecamatan Depok Sleman masih belum menerapkan media pembelajaran IPA berbasis web dalam proses belajar mengajar. Kedua, produk pengembangan media pembelajaran IPA berbasis web berhasil dikembangkan dengan menggunakan langkahlangkah penelitian dan pengembangan dari Borg \& Gall (1983, p.775) dan Alessi \& Trollip (2001, p.410). Software yang digunakan dalam pengembangan media pembelajaran IPA berbasis web ini adalah CMS (Content Management System) Wordpress yang bersifat open source dan dapat digunakan untuk mengembangkan media pembelajaran IPA secara online.

Ketiga, hasil akhir pengembangan produk media pembelajaran IPA ini berupa media pembelajaran IPA berbasis web 
yang dapat diakses secara online di internet melalui alamat url : http://ipa.erwin.web.id. Fitur-fitur yang ada pada aplikasi media pembelajaran web berupa kumpulan materi dalam bentuk teks, gambar, audio, video, animasi, e-book digital, chat, diskusi, soal uji kompetensi dan penilaiannya. Media pembelajaran IPA berbasis web ini sudah diterapkan dalam proses pembelajaran untuk siswa kelas VII di SMP se-Kecamatan Depok Sleman.

Keempat, kelayakan produk media pembelajaran IPA berbasis web berdasarkan hasil evaluasi formatif (uji alpha dan uji beta) menunjukkan: (1) hasil uji alpha melalui validasi oleh ahli media 1 diperoleh rata-rata penilaian sebesar 4,21 dengan kategori "Sangat Baik" dan validasi oleh ahli media 2 diperoleh rata-rata penilaian sebesar 3,93 dengan kategori "Baik" dari skor maksimal 5 sehingga media pembelajaran IPA berbasis web dari aspek media layak digunakan dalam uji coba lapangan utama; (2) hasil uji alpha melalui validasi oleh ahli materi 1 diperoleh ratarata penilaian yakni 3,73 dengan kategori "Baik" dan validasi oleh ahli materi 2 diperoleh rata-rata penilaian 4,23 dengan kategori "Sangat Baik" dari skor maksimal 5 sehingga media pembelajaran IPA berbasis web dari aspek materi layak digunakan dalam uji coba lapangan utama; (3) hasil uji beta yang sudah dilaksanakan oleh peserta didik di SMP Muhammadiyah 2 memperoleh rata-rata penilaian sebesar 4,06 dengan kategori "Baik", SMP N 2 Depok Sleman memperoleh rata-rata penilaian sebesar 4,08 dengan kategori "Baik", SMP N 3 Depok Sleman memperoleh ratarata penilaian sebesar 4,22 dengan kategori "Sangat Baik" dan SMP N 5 Depok Sleman memperoleh rata-rata penilaian sebesar 4,19 dengan kategori "Baik".

Kelima, efektivitas media pembelajaran IPA berbasis web yang didasarkan pada hasil evaluasi sumatif (uji kompetensi pretest dan posttest) dan hasil analisis uji $t$ paired sample t-test menunjukkan bahwa SMP Muhammadiyah 2 memperoleh peningkatan pencapaian hasil belajar sebesar
22,14 dari nilai rata-rata 62,38 menjadi 84,52. SMP N 2 Depok memperoleh peningkatan pencapaian hasil belajar sebesar 24,06 dari nilai rata-rata 62,03 menjadi 86,09 . SMP N 3 Depok memperoleh peningkatan pencapaian hasil belajar sebesar 21,41 dari nilai rata-rata 62,65 menjadi 84,06 dan SMP N 5 Depok memperoleh peningkatan pencapaian hasil belajar sebesar 19,68 dari nilai rata-rata 65,80 menjadi 85,48 . Hasil analisis uji t paired sample t-test menghasilkan nilai $t$ hitung sebesar -37.679 dengan probabilitas 0,000 oleh karena probabilitas < 0,05 maka kedua rata-rata populasi adalah tidak identik (rata-rata nilai pretest dan posttest berbeda secara nyata). Berdasarkan data tersebut menunjukkan adanya perbedaan nilai yang signifikan antara pretest dan posttest hingga tercapainya kriteria ketuntasan mimimal (KKM) dimana nilai pretest lebih rendah jika dibandingkan dengan nilai posttest.

Saran

Produk media pembelajaran IPA berbasis web ini perlu pengembangan dan perawatan (maintenance) lebih lanjut agar dapat dimanfaatkan lebih optimal lagi dan data-data yang ada tetap dapat diakses dengan baik, materi yang disajikan di media pembelajaran berbasis web tidak hanya mata pelajaran IPA tetapi juga mencakup mata pelajaran lainnya, Selain itu, pendidik juga diharapkan mampu memanfaatkan media pembelajaran berbasis web ini untuk meningkatkan hasil belajar siswa.

\section{DaftarPustaka}

AECT. (2004). AECT definition and terminology committee document: the meanings of educational technology. Diambil pada tanggal 27 September 2014, dari: https://www.tlu.ee/ kpata/harid ustehnoloogiaTLU/defineeducation altechnology.pdf.

Alessi M. Stephen \& Trollip R. Stanley. (2001). Multimedia for learning, 
methods and development. United States: Pearson Education Inc.

Asosiasi Penyelenggara Jasa Internet Indonesia. (2015). Profil pengguna internet indonesia 2014. Perpustakaan Nasional Rl: Katalog Dalam Terbitan (KDT). Penerbit: Asosiasi Penyelenggara Jasa Internet Indonesia.

Arsyad, A. (2014). Media pembelajaran edisi revisi. Jakarta: Rajawali Pers.

Borg, W.R. \& Gall, M.D. (1983). Educational research. an introduction. New York: Longman.

Cantillon, P., Jollie, C., and McKimm, J. (2003). Web-based learning. PubMed Center. Vol. 326.

Dick, W., \& Carey, L. (2005). The systematic design of instruction (6 $6^{\text {th }}$ ed). Boston: Person.

Ismaniati, C. (2012). Penggunaan teknologi informasi dan komunikasi dalam peningkatan kualitas pembelajaran. Tidak diterbitkan.

Kemendikbud. (2014). Ilmu pengetahuan alam untuk SMP/MTS kelas VIII buku guru. Jakarta: Kementrian Pendidikan dan Kebudayaan.

Maran, C.M., Selvaraj. C., \& Ravikumar, B. (2011). Effetiveness of multimedia learning in higher education. International Journal of Multimedia Technology, IJMT Vol.1 No.2 2011 PP.8892.

Miarso. Y. (2005). Menyemai benih teknologi pendidikan. Jakarta: Prenata Media.

Rusman. (2012). Belajar dan pembelajaran berbasis komputer mengembangkan profesionalisme abad 21. Bandung: Alfabeta.

Saputro, H. W. (2007). Pengertian website dan unsur-unsurnya. Bandung. Diambil pada tanggal 5 Agustus 2014, dari

http://balebengong.net/teknologi/ 2007/08/01/pengertian-websitedan-unsur-unsurnya.html.

Sukardjo. (2006). Kumpulan materi evaluasi pembelajaran. Yogyakarta: UNY Press.

Supriyono, K., \& Sugirin, S. (2014). Pengembangan media pembelajaran membaca bahasa inggris smp berbasis web. Jurnal Inovasi Teknologi Pendidikan, 1(1), 49-64. Retrieved from

http://journal.uny.ac.id/index.php Ljitp/article/view/2459/2045.

Surjono, H. D. (1999). Pemanfaatan internet untuk memperbaharui model pengajaran di perguruan tinggi. Cakrawala Pendidikan. No.4 (XVII): 162-166.

Surjono, H. D. (2012, Oktober). Implementasi ICT dalam pembelajaran IPA. Makalah disampaikan dalam Seminar Nasional Pendidikan IPA IV di Universitas Negeri Yogyakarta.

Surjono, H. D. (2013). Membangun Course elearning Berbasis Moodle ( $2^{\text {rd }}$ ed). Yogyakarta: UNY Press.

Zhu, J. (2010). The development and applied research of e-learning resources. International Journal of International Conference on e-Education, eBusiness, e-Management and $e$ Learning. 